\title{
THE ARAB SPRING AND CIVIL-MILITARY RELATIONS: A PRELIMINARY ASSESSMENT
}

\author{
Dr Glen Segell, FRGS, \\ The Institute for National Security Studies Tel Aviv*
}

\begin{abstract}
The 'Arab Spring' refers to the wave of civil unrest that covered countries with predominant Moslem populations in North Africa, the Middle East and the Arabian Peninsula, which started late 2010 in Tunisia. The unrests quickly spread across the region, giving rise to the notion of a single inter-related event. However, the results and outcome in each country have been different. This is because each and every country had its own unique political system and unique institutions of state with different relations between power elites. Two institutions of state had prime importance in this political system. These were the executive and the military. In each there was only one important person, the state leader be he president, king, prime minister, emir or sheik or the chief of the armed forces. This article describes that a major cause for the different results and outcomes in each country was determined by the prevailing relations between them, i.e. the civil-military relations.
\end{abstract}

\section{Introduction}

The sociologist Charles Wright Mills describes that each country has its own unique political system and unique institutions of state with different relations between power elites. ${ }^{1}$ Geraint Parry elaborates on the role of elites in politics, seeking to clarify the central terms of elite discourse. ${ }^{2}$ The juxtaposition of these themes is central in the writings of Samuel Huntington who sought to explain the power interplay between the civil elites and the military elites using the term 'civilmilitary relations' (CMR). ${ }^{3}$ This article considers these notions when analysing and describing the different results and outcomes in the various countries that experienced the Arab Spring, and the wave of civil unrest that covered countries with predominantly Moslem populations in North Africa, the Middle East and the

Scientia Militaria, South African Journal of Military Studies, Vol 41, Nr 2, 2013, pp. 42-59.

doi : $10.5787 / 41-2-1067$
Arabian Peninsula, which started late 2010 in Tunisia.

The evaluation of CMR of the Arab Spring in this article shows that one notion or understanding of CMR does not predominate.

\footnotetext{
*Researcher at The Institute for National Security Studies Tel Aviv, lecturer at BarIlan University, senior researcher for the Ariel Research Center for Defense and Communication, and editor of the London Security Policy Study
} 
Inducing a single understanding of the events based on existing CMR theories is not possible. The evidence shows that the results of the events were determined by the willingness or lack thereof of the military to support the incumbent. In each country this differed. Even if the causes of and catalysts in the unrest were the same in all affected countries, the results and the outcomes were different. This is because each state, as both Mills and Waltz have noted, has its own unique political system and unique institutions of state which can lead to conflict. ${ }^{4}$ Hence, no new theory of CMR can be deduced from the events. Similarly, an overriding paradigm cannot be constructed to explain the events.

What was evident in all the countries is that in all such cases, the incumbent state leader has a number of options when faced by protests that call for the removal of his/her regime. He (or she) can reach agreement and compromise with the protestors, leave office willingly or challenge them especially with police or military action. Should such leader decide to use armed force then he/she is reliant on the willingness and capability of the military to support him/her. The military too have a number of options. They can support the leader, turn against him/her or remain neutral, refraining from intervening. There is also the possibility that part of the military will support the leader and part will not. This will lead to a fragmentation of the military, resulting in civil war. Hence, the use of armed forces depends on whether the chief of staff is subservient to the state leader, and whether the military remain a single cohesive institution without fragmenting or defecting.

To explain all of this, this article focuses on the critical moments of decision-making during the unrest associated with the Arab Spring in the relations between the executive and military elites in the affected states. In order to achieve this objective, a research methodology advocated by Scott is used. ${ }^{5}$ Two ambassadors from each of 13 Arab Spring countries were interviewed. Their answers are only quoted - with their consent - when there is consensus in the answers to the same question. This is double-primary sourcing. So the answer given is considered a true and valid response. Neither knew that the other had been interviewed on the same question. The Arab Spring countries do not have freedom of the press. Hence, the use of any journalistic source from those countries would not reflect an objective opinion and would indeed have factual inaccuracies. There are no other available sources of information on the Arab Spring CMR events even if there are many sources on the civil-society side e.g. Facebook and internet blogs. Any translation from any Arabic sources, be they pro-government or pro-opposition or be they Facebook, internet blogs or newspapers, would be word for word and not include or reflect the cultural meaning or innuendo.

Further, the decision to use the ambassadors in these countries as a source is based on their keen insight, understanding and immense inside knowledge of the events. They are all close family or members of the clan of the incumbent leadership and former senior military officers and hence are part and parcel of the decisionmaking to use armed force as described by Jolly in his analysis of such systems of governance. $^{6}$ 
This article is thus based on the decision-makers' responses to essential questions defined by a research framework posed by Pelmutter and Bennet.

- What are the thoughts and action with respect to force in the crucial minutes of crisis?

- Which decision is taken?

- Are the military subservient to the executive?

- Is the military's advice accepted by the executive?

- Do the military at any stage attempt to circumvent the state leader's decision? ${ }^{7}$

\section{Understanding democracy, civil-military relations and strategic culture}

The call for democratisation is an important raison d'être of the Arab Spring. Prior to the Arab Spring, no form of democracy existed in any of the states. To date, the first symbolic element of democracy, namely elections, has taken place in, for example Libya, Tunisia and Egypt. However, elections do not mean that the political system has changed to democracy, nor does it imply the creation of an effective judicial system to protect the rights of individuals. Democracy is not just about elections (procedural democracy) but also about the substantive issues (substantial democracy).

At least four institutions of the state are required to sustain democracy. These are the executive and the legislative of the government, a judiciary (which is independent of both the executive and the legislative), and the military (who are subservient to an elected civil executive). In addition, the four institutions must be able to affect a check and balance on each other and therefore constitute different members who come into office not reliant or dependent upon each other. The system of democracy includes numerous rights and privileges for the individual and society as a whole that cannot be removed by any of the four institutions of state and which must be protected and upheld by them.

The institutions of the executive and the legislative must be constantly accountable to the public by being transparent in their actions. It is through such transparency and accountability that the public can go to the polls to decide on the most suitable candidate based on his/her virtues and actions and based on the political party and its values, ideologies, philosophies and platforms represented by the candidate.

The concept of democracy and its implementation is diverse. Yet, it is indisputable that democracy means that every citizen has the right to express his or her opinion freely. The expression of opinion is manifested in daily life, in the press, in economic activities and in elections for the political leadership of the nation-state. Since the earliest records of democracy in Athens in ancient Greece, the rights of the citizens and the role, authority and legitimacy of state organs are written into 
constitutions, laws, decrees and treaties, to name but a few. It is the role of the legislative and the judiciary to uphold these. Inherent in these since then, is the understanding that democracy is the right to be an individual in a crowd and it also the right of the individual to determine his or her own future.

What is discernible in the Arab Spring countries is that economic conditions under authoritarian and totalitarian regimes were a catalyst to unrest. The unrest called for regime change favouring democracy with the right to elect a new regime as an alternative to the existing regime. This and the mass protests viewed across the world through the medium of television and the Internet did not determine the outcome. In many of the states experiencing the Arab Spring, there have been protests for decades without any changes in leadership or changes in the political systems.

It is the fourth institution of state - the military - which has determined the outcome of the unrest and whether a change of regime has commenced because of CMR. Every country has its own relations between government, the military and society. In each country, the society, the leaders and the armed forces interact and respond with each other in a unique manner. In part, CMR is the process, structure and outcome of decisions made between the elites in the armed forces and the executive of government. This is dependent on the political system.

Welch analyses how in democracies the state controls the military. The military are considered to be subservient and observant to an elected civilian leadership. ${ }^{8}$ This is found both in decisions about when and how to use the armed forces as well as in budgetary decisions on weapons procurement and the size and shape of the armed forces. The military are not used in a domestic context to sustain the president as elections, and not the military, determine who is president. The role of the military is to defend the external borders of the state but without threatening neighbouring states or the region. Elected civilian control of the military ensures the military do not diverge or intervene in the policies of the democratic process and the institutions of the state.

Janowitz's writings provide a framework for understanding how, in nondemocratic states, such as Libya, Egypt and Yemen, the state leadership controls the state through the use of the military domestically. ${ }^{9}$ In these authoritarian states, the state leadership is a former military officer who rose to power through military means. In such instances, there is no separation of authority between the state and the military. The state leader uses the military for domestic reasons against the population to sustain his position of power.

Comparing CMR in different political systems, highlight the role of the armed forces, be it to protect the state against an external threat or to ensure the leader's position within the state. This emphasises the question whether it is legitimate for a leader to use force against his population to sustain his regime. Max Weber's views on the legitimate use of force are relevant to this discussion. ${ }^{10} \mathrm{He}$ 
stressed that the state has the right to exercise legitimate authority of the use of violence over the given territory within its borders. The state may elect to delegate the use of force as it sees fit. In such a delegation, the police and the military become the main instruments to deter such force. However, the state may not use force against its own population in circumstances short of civil war, especially not in the case of peaceful protests based upon economic deprivation.

Hence, the role of the military depends on the unique political system of each country from whence a strategic culture emerges, defined by Colin Gray as the "culture referring to modes of thought and action with respect to force". ${ }^{11}$ Therefore, this article posits that a major cause for the different results and outcomes in countries that experienced the Arab Spring was determined by the modes of thought and action with respect to the use of armed force enacted by the relations (CMR) between them.

Moreover, Colin Gray informs that strategic culture also "flows from geography and resources, society and political structure". ${ }^{12}$ No doubt these factors were instrumental in the different Arab Spring countries offering different results and outcomes. Resources such as oil, for example, were an important consideration in determining the ability of state leaders to provide concessions to the demonstrators and to placate them without resorting to force. This took place in Saudi Arabia, which has oil, but not in Tunisia which does not have oil. Geography (in terms of proximity to Europe) and resources (such as oil) are determinants of external involvement. Such involvement took place when the NATO collective security alliance authorised by United Nations Security Council Resolution 1973 of March 2011 deployed to Libya.

More than the factors of geography and resources are the factors of society and domestic political structure. These are important in determining the different outcomes of the Arab Spring in individual countries. In particular the political structure including CMR has determined whether the state leader has been able to use force against the mass discontent or not. Further, the nature of CMR has determined whether the military have taken advantage of the popular discontent and usurped control of the state.

The incumbent state leader has a number of options when faced by protests that call for the removal of his/her regime. He/she can reach agreement and compromise with the protestors, leave office willingly - or challenge them, especially with police or military action. Should he/she decide to use armed force, then he/she is reliant on the willingness and capability of the military to support him/her. The military too have a number of options. They can support the leader, turn against him/her or remain neutral, refraining from intervening. There is also the possibility that part of the military will support the leader, and part will not. This will lead to a fragmentation of the military, resulting in civil war. Hence, the use of armed forces depends on whether the chief of staff is subservient to the state leader 
and whether the military remain a single cohesive institution without fragmenting or defecting.

\section{Categorising civil-military relations during the Arab Spring}

In many of the affected countries, unrest was not a new phenomenon. It was the rapid spread of demonstrations across so many countries with the same demands that was astounding. Without regard to the causes, the results could not be predicted. In every country, the state leader and the chief of the armed forces had unique modes of thought and actions to the use of armed force against civilian protestors. Every country had unique CMR in implementing the use of armed force against civilian protestors. In most instances in the past in these countries, the response had been to quell the demonstrations with force. Analysis based on past cases would have predicted the quelling of demonstrations with force. However, this time, the responses in individual countries differed.

An analysis at the core four states of the Arab Spring highlights the differences. Armed force was used in Libya and in Yemen but not in Egypt and Tunisia. In Tunisia, the military refused to support the president, leading to democratic elections. In Egypt, the military effected a bloodless palace coup, leaving the street protestors empty-handed. In Libya, the military fragmented into two groups, with elements supporting Gaddafi and elements defecting to the opposition, leading to a bloody civil war and NATO intervention. In Yemen, a large part of the military defected to the opposition, leading to a civil war, Saudi intervention and the vice-president assuming power.

In Libya, Egypt and Yemen, former members of the ruling government took advantage of the situation to replace their predecessors. There was thus a change in the leadership of the regime without a change of the regime.

Hence, there emerged three categories:

- Those affected countries whose civil leadership offered concessions and reforms without the use of force;

- Those countries where the military did not support the civil leadership; and

- Those countries where the military supported the civil leadership but fragmented or defected.

Based upon the interviews with the ambassadors, this article continues to detail these categories.

\section{Category 1: Civil leadership concessions and reforms without the use of force}

The first category described by Janowitz comprised those countries where the mode of thought and action with respect to force by the state leader was not to use the military against civilians who were protesting and where the military in a display of professionalism agreed. ${ }^{13}$ The political elites preferred to offer 
concessions to the protestors through a political process. Despite this, the police and military were deployed to protect government installations and as a deterrent. The rational decision for not issuing the command to quell the protests with armed force ensured that the leaders remained in power without substantial changes to their political system and without aggravating the international community.

In part, this reflects a maturing political system with a tendency towards stability that is able to manage crisis situations without resorting to violence. On the other hand, this reflects the leader's position of political strength and his/her ability to wield his/her political power effectively. Furthermore, it reflects the notions described by Edmonds as the military knowing its place in society as not being against society. ${ }^{14}$ This also reflects the perception of society that their discontent could be addressed through protests, even though in many cases they are aware that the offer of concessions may never be fulfilled completely or within the promised timescales. Nevertheless, the mere offer of concessions has given the society the feeling that they have the ability to influence events. Consequently, the protestors have been placated and the unrests have subsided.

States in this group include Bahrain, which experienced extreme civil protests starting in February 2011. When the clashes between the police and the demonstrators escalated there was a call for the end of the monarchy. The king consulted with his generals - in particular Shaikh Daij bin Salman Al Khalifa- and the American military, whose $5^{\text {th }}$ Fleet is headquartered in Bahrain. The advice was that the discontent was a continuance of the decades of Shiite and Sunni disputes, making Bahrain a proxy battle field between Iran and Saudi Arabia. The generals advised that escalating armed force against the demonstrators would not quell them and that economic concessions had to be offered. To assist, the king called on other Sunni Gulf Cooperation Council (GCC) countries as a show of strength and solidarity against Iran. Amongst them, Saudi Arabia and the United Arab Emirates (UAE) sent forces to protect infrastructures and to secure key installations, while Kuwait sent its navy into Bahraini waters. This show of solidarity combined with the constraint of force against the demonstrators was a stabilising element. ${ }^{15}$

Sudanese president, Omar Hassan Ahmad al-Bashir, offers another example. In deliberations with his military staff after demonstrations had started on 17 January 2011, he expressed concern that the unrest was connected to the battles waging in two separate and unconnected wars, namely in the western Darfur province and in the south of the country with the newly independent Republic of South Sudan over the oil fields. Sudanese intelligence services assured that there was no indication of either being involved in the demonstrations in Khartoum. The response was therefore a containment of the demonstrators using police by means of a dusk-to-dawn curfew and the setting up of roadblocks to check identity documents. To placate the demonstrators' call "to end the regime", he announced his intent not to stand for office in the next elections in 2015. 
These indicated two important events that had not been observed previously in Sudan since al-Bashir's rise to power in 1989. First, he did not use armed forces against the demonstrators. The use of armed force against dissenters has been a predominant feature of his rule. Al-Bashir made this decision based on military advice. Secondly, his announcement empowered the people who viewed the statement as the weakening and aging of a once all-powerful dictator. Hence, the president bought time but at the same time reduced his political time by revealing weaknesses of leadership. Both the demonstrators and his military chiefs were aware of this. ${ }^{16}$

Prime Minister Nouri al-Maliki of Iraq made a similar announcement, namely that he would not run for a third term in the elections of 2014 after unrest which started on 10February 2011. However, the political system and structure and hence the situation in Iraq are different from that of Sudan. The population of Iraq is still struggling with the transition from the authoritarian rule of President Saddam Hussein while a tension remains between the majority Shiite population and the Sunni militia. The understanding of post-Saddam Iraq implemented with American assistance was for a system of democracy. Hence, al-Maliki was under pressure not only from the demonstrators but also from his military staff and the United States and NATO. Any element of potential indecision was swept away when President Jalal Talabani,who has no executive role and who is Kurdish, took the initiative and stated that he was adamant that military forces were not an option as this would be reminiscent of Saddam Hussein's dictatorial regime. Al-Maliki accepted this decision, making his announcement while subsequently there were further offers of resignation of provincial governors and local authorities. ${ }^{17}$

In both Sudan and Iraq, promises by the leaders have been heard in the past and were not adhered to. In both countries, similar events in the past have resulted in their governments' use of the military to quell the protests. The announcements coupled with the lack of the use of force resulted in placating the demonstrators. This indicated that the mere ability to bring the leader to offer his resignation was sufficient. Such an offer from a dictator clearly gives protestors symbolic power. In both instances the military were subservient to the executive and did not see a threat to the state that required military action. They saw the events as a direct threat to the executive leader, who accepted the advice offered to him while the military did not use the events as an opportunity to usurp power and effect a coup d'état.

Jordan became the sixth country to face unrest. The political system in Jordan as a parliamentary monarchy is different from that of Sudan and Iraq. The majority of the population of Jordan are Sunni Palestinians and the minority Hashemite King Abdullah II bin Hussein al-Hashimi constantly has to tread a fine line to ensure his survival of rule. In order to do so, the king relies on his religious roots of the Hashemite tribe being the direct descendants of Fatima, the daughter of the Prophet Mohamed, rather than through the imposition of his rule by using his military. Many of the 2500 protesters in the initial unrest were identified as members of the Islamic Action Front, the main opposition to the government. Being 
part of the political system with identifiable leadership enabled the king to enter negotiations and offer compromises to placate them.

Police were deployed to maintain law and order while Prime Minister Rifai and his cabinet were dismissed beginning a process of reforms for an elected cabinet and prime minister. Following slow progress, Prime Minister Bakhit and his cabinet were dismissed four months later. These placated the demonstrators though at one crucial point, the military elites joined the economic complaints. On orders from the king, the Chief of the Joint Staff of the armed forces, Lieutenant General Mashaal Muhammad al-Zaben, increased the wages and benefits of the military, and held a large military exercise in the desert against a conventional threat. Keeping the military well fed and occupied was viewed as a good policy and was successful as was the offer of concessions to the public, though the Hashemite king as a minority will always be in a precarious position. ${ }^{18}$

Saudi Arabia offers a similar example of economic and political concessions, though the ruling monarchy is a majority with popular support and close family ties between the civil and military elites. Unrest started on 21 January 2011 but was not a new phenomenon. The demonstrations were held by domestic women's movements and in the eastern provinces adjacent to Bahrain, by minority Shiite movements inspired by Iran. King Abdullah bin Abdulaziz al-Saud made immediate economic concessions, informed the nation of forthcoming municipal elections, promised women the right to vote and to be elected in municipal elections in 2015, and to be nominated to the Shura Council. These were well received by the domestic dissenters but did little to alleviate the Shiite protests that continued in the eastern province.

At no stage was the regime in danger of falling, though long-term strategy was considered essential by the king. The consensus in consultations with military elites was that the Arabian Peninsula and indeed Sunni Islam was one inseparable entity. When asked by the Saudi King, Defence and Aviation Minister Crown Prince Sultan bin Abdulaziz al-Saud and Chief of General Staff Lieutenant General Salihibn Ali al-Muhaya informed him that their country, which was predominately desert, had no defensible borders. They noted that they were doing their utmost to counter Iranian influence, including the provision of arms and advice to rebels in Libya and Syria and deploying forces to Bahrain. They suggested the way forward was to create a Sunni caliphate state encompassing all of the Arabian Peninsula. This was accepted by the king and Saudi diplomats were instructed to call for the formation of a closer union at an extraordinary summit of the GCC in Riyadh on 14 May 2011. ${ }^{19}$

Initially, the GCC states of Qatar, Oman and the UAE were non-committal. These states had not experienced any significant domestic unrest. The Saudi diplomats stressed to the UAE that this was a logical progression of the already federal UAE to include five additional states but under the leadership of Saudi Arabia, because it was the custodian of the Holy Sites. The UAE Head of State 
Shaykh Khalifa bin Zayed Al Nahyan, emir of Abu Dhabi conferred with the other six emirs of the UAE. There was consensus that the very strong appeal of an Arabian caliphate state was not sufficient to overcome their political, economic and military sovereignty. Qatar and Oman emphasised that the Saudi offer was related to domestic unrest that they had not experienced nor were likely to and hence the offer was not appealing. The debate then focused on the eventuality of an external military threat, such as Iran, where it was acknowledged that should this occur they would assist each other. ${ }^{20}$

While the Saudi proposal had little impact on these it did sway Kuwait into a notional agreement of greater unity. Kuwait had experienced demonstrations since 18 February 2011, with the dissolution of parliament and resignation of Prime Minister Nasser Mohammed Al-Ahmed Al-Sabah as offers of concession. Kuwait, like Saudi, has a ruling monarchy with a popular majority support and close family ties between the military and the civil elites. However, its one million citizens are dwarfed by two million foreign workers. This, together with the omnipresent legacy of the Iraq invasion in 1990 and the American liberation in 1991, leads to the acceptance of Kuwaiti vulnerability. Kuwait, even should it wish to, would not be able to use its small military successfully against mass unrest by foreign workers and against another Iraqi or even Iranian invasion. Kuwait Emir Sabah Al-Sabah and his close relative the chief of staff Lieutenant General Khaled Al-Jarrah Al-Sabah reached the notional agreement with their Saudi counterparts that tutelage under Saudi rule was a foregone conclusion but without a fixed date. ${ }^{21}$

Of all the states in the GCC, Bahrain head of state Amir Sheikh Hamad bin Isa al-Khalifa and his commander in chief of the armed forces Lieutenant General Khalifa bin Ahmed al-Khalifa were the most conducive to the Saudi initiative. In consultations with the Saudi chief of staff Lieutenant General Huseen ibn Abdullah al-Gubayel, they noted the vulnerability of the 33 islands (six inhabited) that comprise their state, to the "Iranian Shiite insurgency". They stressed their gratitude for the assistance already provided by Saudi, the UAE and Kuwait against the unrests in accordance with the 1985 Bahrain Agreement. They accepted the notion of unity with the provision that all GCC countries had to agree as there would not be a bi-lateral merger with Saudi Arabia. ${ }^{22}$

A common element amongst this category of states was the observance that the military, at all ranks, had for the civil leadership. The military acted as a unitary actor without fragmenting, granting the political leader sole authority and obeying that authority. Given that many of these states are authoritarian based upon domestic military control, it would appear that they are experiencing a decline in the military regime described by Danopoulos. ${ }^{23}$ The civil leadership aimed at resolving any unrest peacefully, calling on police where necessary to maintain law and order and not the military. The military adhered to these decisions, offering advice when requested and without attempting to leave their barracks. This was also prevalent in the debates over the Saudi offer. 
This was a unique occurrence in a region where a primary role of the military is domestic and not the defence of the sovereign state from an external threat. It is unique given the history of coups and military revolutions in the region. It leads to the conclusion of a well-trained military, an excellent command structure and the subservience of the military to civil leadership and also of the notions of Sarkesian that show a new military professionalism to stay out of the affairs of state. ${ }^{24}$ It also gives rise to the conclusion of maturing political systems according citizens respect in offering concessions and reconciliations without resorting to the use of armed force even if the leadership is authoritarian/totalitarian.

\section{Category 2: No military support for civil leadership}

The second category consists of the type of authoritarian military regime countries described by Galbraith. ${ }^{25}$ In these types of states, the mode of thought and action by the state leader with respect to armed force is traditionally to use the military in an offence against civilians who are protesting. However, in Tunisia and Egypt, in this instance, the military did not support the decision. In both states, the presidents:

- Had military backgrounds and had entered their protracted rule through an event similar to their demise: revolt, revolution or coup;

- Were unable or unwilling to enter negotiations with the demonstrators to offer political and/or economic concessions; and

- Considered and tried to use the military to quell the demonstrations but in both cases, the military decided not to respond in a fashion that would ensure the position of the president.

In doing so, the militaries of Tunisia and Egypt turned on their benefactors resulting in quick transfers of power and relatively little bloodshed. Feaver describes such events as the "officer corps professionally formed cohesion" ${ }^{26}$ while Sarkesian calls it "institutional autonomy". ${ }^{27}$ The cases in the two countries are similar in this aspect but different because of the exacting nature of the modes of thought and action with respect to the use of force, and of CMR in each country.

On 17 December 2010, Tunisia was the first country to experience unrest about social, economic and political issues. Prime Minister Ghannouchi resigned and on 14 January 2011, President Zineel-Abidine Ben Ali stepped down as president after 23 years, fleeing to Saudi Arabia. The rift between the president and the military was evident when Chief of Staff Rachid Ammar refused the president's order to fire on demonstrators. This was not surprising as Tunisian leadership had been at protracted odds with its military since independence. The first president of the Republic Habib Ali Bourguiba (July 1957-November 1987) ensured that the military would never play any significant role as an institution of the state. An attempted coup against him in 1962 led to the execution or imprisonment of key officers. His successor President Zine El Abidine Ben Ali (November 1987-January 2011) cracked down even further, reducing the military to fewer than 40000 , 
delayed promotions, introduced compulsory retirement and imprisoned officers belonging to Islamic groups to reduce any threat to his regime. Given no external threat and no natural resources, such as oil, to attract such a threat, defence spending was curtailed to $1,4 \%$ of the country's gross domestic product (GDP). Hence, the military had neither capability nor propensity to function in any manner and especially not in a domestic context to prop up the President. ${ }^{28}$

In neighbouring Egypt, following 18 days of civil protest on social, economic and political issues starting on 25 January 2011, President Hosni Mubarak resigned after 29 years in office. Following this, the prime minister resigned, parliament was dissolved, the constitution was suspended, and the State Security Investigations Service was disbanded as was the ruling party of Egypt. Its assets were transferred to the state and a process was started to prosecute Mubarak, his family and his former ministers. A Supreme Council of the Armed Forces took control of the state, writing a new constitution and holding multi-party elections for parliament and presidency.

Unlike in Tunisia, the armed forces in Egypt are the largest in the Arab world, the largest in Africa and the $16^{\text {th }}$ largest in the world. They also hold vast economic interests. When street protests commenced, President Mubarak, a former military officer, called on the Minister of Defence and Military Production Field Marshal Hussein Tantawi, and chief of general staff Lieutenant General Sami Hafez Anan. They refused to concede to his orders to deploy troops with the intent of putting down the protests with the use of force. The president called in the palace guard to arrest the generals and the palace guard refused. Commanders of police units from the Ministry of the Interior deployed to quell demonstrations in Cairo's Tahrir Square informed demonstrators that they would not obey orders to shoot if these were given. At all levels in the Egyptian military, there was a propensity to refuse orders, altruistically preserving their own and their institutional well-being and status. A bloodless palace coup coupled with insubordination was the conclusion leading to a rapid transfer of leadership. ${ }^{29}$

The common element amongst this category of states is the lack of observance that the military, at all ranks, had for the state leadership. The military were simply not willing to act as a military force domestically. They were not willing to adhere to the orders of the state leader; however, they were also not inclined to intervene to support the unrest. This was a unique occurrence in a region where a primary role of the military is domestic and not defence of the sovereign state from an external threat. It is unique given the history of coups and military revolutions in the region as detailed by Kamrava. ${ }^{30}$ It leads to the conclusion of a weak command structure and the insubordination of the military to both civil and military leadership. Lazy and indifferent could best describe their attitude.

Category 3: Military support for civil leadership but fragmented or defected 
This category consists of countries where the mode of thought and action by the state leader with respect to armed force was to use the military in an offence against civilians who were protesting in one of the roles of CMR described by Huntington. ${ }^{31}$ Libya and Yemen fall in this category. In both cases, the:

- Presidents had military backgrounds;

- Presidents had entered their protracted rule through an event similar to their demise: revolt, revolution or coup;

- Presidents were unwilling to enter negotiations with the demonstrators to offer political and economic concessions; and

- Leadership chose to pursue a vicious and violent attempt to retain leadership by ordering the military elite, who obeyed, to quell the demonstrations.

This can be explained by the personal propensity of the state leader to do so; his character or psychology. It can also be explained by the leader's ability and capability to do so. CMR literature ascribes the willingness of the military elite to support their presidents in Libya and Yemen resulting from an intertwining of the military and government with various social groups such as sects, families, regions and tribes. $^{32}$

The military elite supported the decision but were unable to implement it successfully because the military fragmented or defected and civil war raged before their demise. The catalyst for the fragmentation and defections was external intervention. In Libya, this was by an international coalition and then NATO, and in Yemen, by Saudi Arabia. This forced the military at all levels to make an existential decision where fighting for the incumbent was not a good option as the tide of the battle had turned. The cases in the two countries are similar in this respect but different because of the exacting nature of the modes of thought and action with respect to the use of armed force, and hence CMR in each country.

In Libya, sporadic unrest commenced on 17 February 2011 and continued until 23 October 2011. Colonel Gaddafi, who had ruled Libya from 1969, chose to respond with military force. He had the ability and propensity to do with a personnel legacy of violence. His elite forces, some mercenary, were formed into brigades as 'regime protection units' located near the capital, Tripoli, strategic sites and his homes. They were commanded by family members who relished the prospects of battle. However, in the vicinity of the eastern city of Benghazi, regular forces - half of them conscripts who were not as closely connected to his regime and without the same tribal/family links and benefits - dropped their arms or defected while citizens took to arms.

United Nations Security Council Resolutions 1970 and 1973 in March 2011 mandated an international coalition from March to October to engage in a sea arms embargo, a no-fly zone and striking of targets used against civilians by air power support. This was implemented by an international coalition including NATO, Qatar, 
Sweden, Ukraine, Morocco and the UAE in support of the opposition National Transitional Council (NTC). In doing so, a bloody civil war ensued resulting in a change of regime. NATO decided to intervene because of the geographic proximity of Libya to Europe, the potential threat to Mediterranean shipping and Libyan oil resources. There were defections including, in May 2011, five generals, two colonels and a major to Italy via Tunisia and then Foreign Minister Abdel Rahman Shalgam and Minister of Justice Mustafa Abdul Jalil. The later would become the new president after Gaddafi's death on 20 October 2011. Without NATO intervention, Gaddafi may have won, as his forces were loyal and strong enough to counter the unrest. The fragmentation and defections occurred once NATO had turned the tide of the battle. ${ }^{33}$

Yemen has had unrests that have been ongoing for decades. Another wave of civil unrest starting on 27 January 2011 was no surprise. President Ali Abdullah Saleh ordered the military out of barracks to quell the protestors. He certainly had the capability. Yemen spends $40 \%$ of its GDP on the military having built up its forces for domestic use since independence in 1960. The military elite and the army obeyed as they are well attuned to domestic deployment including civil war (1994), armed rebellion of Sunni Salafists (since 2000), Al-Qaeda in the Arabian Peninsula (since 2010), Huti northern clan (since 2004), and southern separatists (since 2009).

The turn in the tide of the battle came a month into the unrest with the defection of political and military partners including those from the president's own tribe, the Hashid. Major General Ali Mohsen al-Ahmar (1st armoured division), defected, taking hundreds of troops and several tanks. The 119th Brigade also defected, and both launched repeated offensives against loyal government forces including fierce fighting in the capital. Following pressure from Saudi Arabia, the president transferred leadership to Vice President Abed Rabbo Mansour Hadi and went into exile in Saudi Arabia, which decided to intervene because of the proximity of the conflict to its own borders, the radicalisation of areas of Yemen that could spread to Saudi Arabia and their desire for a Yemini leader who would be more conducive to their own plans for the region. In effect, a civil war, a palace coup and external intervention changed the leadership of the regime but not the type of regime. The military remain fragmented as are large parts of the country under tribal or terrorist rule. ${ }^{34}$

The common element amongst this category of states is the observance that the military, at all ranks, had for the state leadership, at the onset of the unrest. In Libya and Yemen, the military were willing to act as a military force domestically to support the president, at the onset of the unrest. They were willing to adhere to the orders of the state leader against civilian protestors. However, as time progressed external intervention was a catalyst for opportunist officers to fragment and defect as described by Kalko as "he changing process of domestic politics in a war situation". ${ }^{35}$ External intervention turned the tide of the battle causing the military to conclude that their future lay not with the incumbent. This lead to the conclusion of 
a weak command structure the insubordination of the military to both civil and military leadership and an opportunist military lacking loyalty.

\section{Conclusion}

Although individuals and social movements need opportunity, strategy and capacity to organise, success is based on the response of the incumbent rule. The outcome of the simultaneous unrest in numerous countries in North Africa, the Middle East and the Arabian Peninsula since 2010 could neither have been predicted nor predetermined. Every country has a unique political system. The different outcomes in countries are attributed to different modes of thought and action with respect to armed force and different CMR. The decision of a state leader to use force or not, his/her ability to control and use the military and the desire and ability of the military to support the leader determines the outcome of any unrest.

What emerged from the events are three categories of CMR:

- Those affected countries whose civil leadership offered concessions and reforms without the use of force;

- Those countries where the military did not support the civil leadership; and

- Those countries where the military supported the civil leadership but fragmented or defected.

In instances where the state leader made concessions and negotiated, he remained in power, for example Jordan, Iraq, Sudan and Bahrain. This has also been the case in instances where the military totally supported the state leader, for example Saudi Arabia. In instances where the military have refused to support the state leader, the leader has fallen, for example Tunisia and Egypt. Where the military have fragmented or defected, there has been violent civil conflict, followed by the fall of the state leader, for example Libya and Yemen. External intervention played a major part in the fragmentation and defections, such as in the case of Libya and Yemen. Such an observation should have been obvious to the leaders of Libya, Egypt, Tunisia and Yemen. Their demise was through an event similar to their rise to power: revolt, revolution or a coup by those younger, more aspiring and more able to invoke the loyalty of their followers.

In the immediate demise of the former leader, the new leadership in Egypt, Libya and Yemen were elites from the previous government. They usurped the unrest movement and its goals and took control: in Libya, the former Minister of Justice, in Egypt the Supreme Council of the Armed Forces and in Yemen the former Vice-President. In Libya and Yemen, the military structures have disintegrated and large areas of the country are no longer under control of the capital. Maintaining stability through a strong hand and a threat of armed force may become the means to ensure law and order.

Time will tell if there will be a true change in regime and not just a change in leadership. Elections have already been held in Tunisia, Egypt and Libya. Not all 
of these have brought about the changes hoped for by the protestors. Unrest continues and the new governments are fragile. If the new leadership grasps that their future lies not in the past in using the military as a domestic institution of state to control society and as a palace guard but in modes of thought and action with society and not with armed force. This reformed two other institutions of state, the legislature and the judiciary, and did so by ensuring the military are subservient to an elected civil executive. In doing so, an example might have been set by those countries whose civil leadership offered concessions and reforms without the use of armed force. The leaders of Algeria, Bahrain, Iraq, Jordan, Kuwait, Lebanon, Morocco, Mauritania, Oman, Saudi Arabia, Sudan and Western Sahara (the Sahrawi Republic) are still in office and their military elites are still subservient to them.

Given this, the evaluation of CMR of the Arab Spring in this article shows that one notion or understanding of CMR does not predominate. This supports Mills and Waltz's notions that each state has its own unique political system and unique institutions of state. ${ }^{36}$ Even if the causes and catalysts were the same in the unrest in all the countries, the results were different. A paradigm cannot be constructed from the theories resulting from analysis of the events. Inducing an understanding of the events based on existing CMR is not possible. The evidence shows that the results of the events were determined by the willingness or lack thereof of the military to support the incumbent. There was no overriding reason why they would or would not do so. Similarly, no new theory of CMR can be deduced from the events. This is because the outcome in each and every country was different because each state has its own unique political system and unique institutions of state.

\section{Endnotes}

${ }^{1}$ Mills, W. The power elite. London: Oxford University Press, 1956.

${ }^{2}$ Parry, G. Political elites. London: Allen and Unwin, 1980.

${ }^{3}$ Huntington, S. The soldier and the state: The theory and politics of civil-military relations. Cambridge, MA: Belknap Press of Harvard University, 1957.

${ }^{4}$ Waltz, K. Man, the state and war. New York: Columbia University Press, 1959.

${ }^{5}$ Scott, J. The sociology of elites. Aldershot Hants: Edward Elgar, 1990.

${ }^{6}$ Jolly, R. Military man, family man. London: Brasseys, 1987.

${ }^{7}$ Pelmutter, \& Bennet, V. The political influence of the military. New Haven, CT: Yale University Press, 1980.

${ }^{8}$ Welch, C. Civilian control of the military: Myth and reality. Albany, NY: State University of New York Press, 1976.

${ }^{9}$ Janowitz, M. Civil military relations: Regional perspectives. Beverly Hills, CA: Sage, 1981.

${ }^{10}$ Weber, M. Politics as a vocation. Philadelphia, PA: Fortress Press, 1965.

${ }^{11}$ Gray, CS. Modern strategy. Oxford: Oxford University Press, 1999. 
${ }^{12}$ Gray, CS. "National style in strategy: The American example”. International Security 6/2. 1981. 22.

${ }^{13}$ Janowitz, M. The professional soldier. Glencoe, IL: Free Press, 1960.

${ }^{14}$ Edmonds, M. Armed services and society. Leicester: Leicester University, 1988.

${ }^{15}$ Interviews with the Ambassador of Bahrain to Britain, Mrs Alice Thomas Samaan, 6 July 2012, at the Bahrain Embassy London, and the Ambassador of Bahrain to France, Dr Nasser Al Belooshi, 7 July 2012, at the Bahrain Embassy Paris.

${ }^{16}$ Interviews with the Ambassador of Sudan to Britain, Hassan Abdin, 6 July 2012, at the Sudan Embassy London, and the Ambassador of Sudan to Spain, Abdalla Ahmed Hassam Salim, 29 June 2012, at the Sudan Embassy, Madrid.

${ }^{17}$ Interviews with the Ambassador of Iraq to Britain, Salah Al Shaikhly, 6 July 2012, at the Iraq Embassy London, and the Ambassador of Iraq to Spain, Talal H Al-Khudairi, 29 June 2012, at the Iraq Embassy Madrid.

${ }^{18}$ Interviews with the Ambassador of Jordan to Britain, Mazen Kemal Mahmoud Houmoud, 8 July 2012, at the Jordan Embassy London, and the Ambassador of Jordan to Spain, Zaid Al-Lozi, 30 June 2012, at the Jordan Embassy Madrid.

${ }^{19}$ Interviews with the Ambassador of Saudi Arabia to Britain, His Royal Highness (HRH) Prince Mohammed Bin Nawaf Bin Abdulaziz Al-Saud, 8 July 2012, at the Saudi Embassy London, and the Ambassador of Saudi Arabia to Spain, HRH Prince Saud Bin Naif bin Abdulaziz Al-Saud, 30 June 2012, at the Saudi Embassy Madrid.

${ }^{20}$ Interviews with the Ambassador of the United Arab Emirates (UAE) to Spain Dr Hessa Abdullah Al Otaiba, 1 July 2012, at the UAE Embassy Madrid, and the Ambassador of the UAE to Britain, Abdul rahman Ghanem Almutaiwee, 9 July 2012, at the UAE Embassy London.

${ }^{21}$ Interviews with the Ambassador of Kuwait to Britain, Khaled Al Duwaisan, 10 July 2012, at the Kuwait Embassy London, and the Ambassador of Kuwait to Spain, Jeque Salem Al-Jaber Al-Ahmad, 1 July 2012, at the Kuwait Embassy Madrid.

${ }^{22}$ Interviews with the Ambassador of Bahrain to Britain, Mrs Alice Thomas Samaan, 6 July 2012, at the Bahrain Embassy London, and the Ambassador of Bahrain to France, Dr Nasser Al Belooshi, 7 July 2012, at the Bahrain Embassy Madrid.

${ }^{23}$ Danopoulos, $\mathrm{C}$ (ed). The decline of military regimes: The civilian influence. Boulder, CO: Westview Press, 1988. 
${ }^{24}$ Sarkesian, S. Beyond the battlefield: The new military professionalism. New York: Pergamon Press, 1981.

${ }^{25}$ Galbraith, JK. How to control the military. New York: New American Library, 1969.

${ }^{26}$ Feaver, PD. "The civil-military problematique: Huntington, Janowitz, and the question of civilian control". Armed Forces and Society 23/2. 1996. 149-178.

${ }^{27}$ Sarkesian, SC. The professional army officer in a changing society. Chicago, IL: Nelson-Hall Publishers, 1975.

${ }^{28}$ Interviews with the Ambassador of Tunisia to Britain, Mohamed Ghariani, 11 July 20112, at the Tunisia Embassy London, and the Ambassador of Tunisia to Spain, Habib M'Barek, 2 July 2012, at the Tunisia Embassy Madrid.

${ }^{29}$ Interviews with the Ambassador of Egypt to Britain, Hatem Seif El Nasr, 11 July 2012, at the Egypt Embassy London, and the Ambassador of Egypt to Spain, Yasser Murad Osman Hosny, 2 July 2012, at the Egypt Embassy Madrid.

${ }^{30}$ Kamrava, M. "Military professionalization and civil-military relations in the Middle East". Political Science Quarterly 115/1. 2000. 67-92.

${ }^{31}$ Huntington, S. The soldier and the state. Oxford: Oxford University Press, 1957.

${ }^{32}$ Be'eri, E. Army officers in Arab politics and society. New York: Praeger, 1970; Rustow, D. The military in Middle East politics and society. Columbus, $\mathrm{OH}$ : Ohio State University Press, 1963.

${ }^{33}$ Interviews with the Ambassador of Libya to Britain, Mohamed Abu Al Qasim Azwai, 12 July 2012, at the Libya Embassy London, and the Ambassador of Libya to Spain, Abdulwahed R. Gammudi, 3 July 2012, at the Libya Embassy Madrid.

${ }^{34}$ Interviews with the Ambassador of Yemen to Britain, Mohamed Taha Mustafa, 12 July 2012, at the Yemen Embassy London, and the Ambassador of Yemen to Spain, Abdulrahman Kamarani, 3 July 2012, at the Yemen Embassy Madrid.

${ }^{35}$ Kalko, G. The politics of war. New York: Pantheon Books, 1990.

${ }^{36}$ Mills op. cit.; Waltz op. cit. 